\title{
Village of Immigrants
}




\section{Rivergate Regionals}

Rivergate Regionals is a collection of books published by Rutgers University Press focusing on New Jersey and the surrounding area. Since its founding in 1936, Rutgers University Press has been devoted to serving the people of New Jersey and this collection solidifies that tradition. The books in the Rivergate Regionals Collection explore history, politics, nature and the environment, recreation, sports, health and medicine, and the arts. By incorporating the collection within the larger Rutgers University Press editorial program, the Rivergate Regionals Collection enhances our commitment to publishing the best books about our great state and the surrounding region. 


\section{Village of Immigrants §ิ \\ LATINOS IN AN \\ EMERGING AMERICA}

Diana R. Gordon

RUTGERS UNIVERSITY PRESS

NEW BRUNSWICK, NEW JERSEY, AND LONDON 
Library of Congress Cataloging-in-Publication Data

Gordon, Diana R.

Village of immigrants : Latinos in an emerging America / Diana R. Gordon. pages $\mathrm{cm}$. - (Rivergate regionals)

Includes bibliographical references and index.

ISBN 978-0-8135-7590-2 (hardcover : alkaline paper) - ISBN 978-o-8135-7591-9 (ePub) - ISBN 978-0-8135-7592-6 (Web PDF)

1. Hispanic Americans-New York (State)-Greenport-Social conditions. 2. Immigrants-New York (State)-Greenport-Social conditions. 3. Working class-New York (State)-Greenport-Social conditions. 4. Hispanic Americans-New York (State)Greenport-Biography. 5. Immigrants-New York (State)-Greenport-Biography. 6. Working class-New York (State)-Greenport-Biography. 7. Social change-New York (State)—Greenport. 8. Greenport (N.Y.)—Ethnic relations. 9. Greenport (N.Y.)Biography. 10. Greenport (N.Y.) -Economic conditions. I. Title.

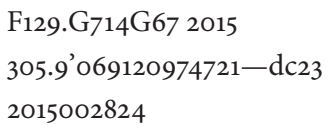

A British Cataloging-in-Publication record for this book is available from the British Library.

Copyright $\odot 2015$ by Diana R. Gordon

All rights reserved

No part of this book may be reproduced or utilized in any form or by any means, electronic or mechanical, or by any information storage and retrieval system, without written permission from the publisher. Please contact Rutgers University Press, 106 Somerset Street, New Brunswick, NJ 08901. The only exception to this prohibition is "fair use" as defined by U.S. copyright law.

Visit our website: http://rutgerspress.rutgers.edu

Manufactured in the United States of America 